\title{
Ideology, Rhetoric and Argument
}

\author{
MICHAEL WEILER Emerson College
}

Key Words: Ideology; rhetoric; argumentation; rhetorical criticism; legitimation; authority; power; political philosophy.

\begin{abstract}
Rhetorical criticism examines ideology as a form of strategic argumentation that functions to legitimize political authority. Ideology presents itself as political philosophy in a way that calls attention to its argumentation. Ideological arguments support claims (1) that those who wield political power represent the interests of all, and (2) that the existing social order is natural and inevitable in light of human nature. Functionally, ideology is indispensible, but perverse. Formally, ideology is argumentation that obscures its partiality under claims to universality.
\end{abstract}

My purpose in this essay is to investigate what a rhetorical perspective might contribute to the criticism of ideology. Another way of putting this is to ask whether and in what ways ideology can be viewed as rhetoric. I will suggest that though ideology can be located at a number of different linguistic levels, and in a number of rhetorical and perhaps even non-rhetorical forms, the concerns of the critic of rhetoric and the critic of ideology coincide most clearly and productively at the point where ideology is seen as a type of strategic argumentation.

The criticism of thetoric describes, explains and evaluates the effects of forceful expression on audiences. ' It investigates instances of persuasive discourse, discourse designed to influence the attitudes, beliefs and/or actions of real people in real situations.

Rhetorical criticism's subject matter ranges across a spectrum of discursive forms: from inaugural addresses to commercial advertisements; from political novels to high school textbooks. Its range of contexts is similarly broad: from presidential campaigns to corporate seminars; from PTA meetings to private conversations. And its range of methods reflects this breadth as well: from voter survey research to close textual reading; from participant observation to content analysis. Amid this near infinite variety, however, there is always rhetorical criticism's unique focus: the triangular relationship of persuasive discourse, audience and effect. ${ }^{2}$

Rhetorical criticism of ideology presupposes that ideology takes the form of persuasive discourse. At a minimum, this means that ideology must be isolable as a verbal text, must be addressed to an actual audience, and must aim at persuasion.

Understood as a species of rhetoric, ideology is both generic and unique. Ideology, like all rhetoric, may employ the full range of inventional and figural resources, but presents itself primarily as political philosophy. Ideology, like all rhetoric, is addressed to audiences, but by its nature obscures the differences among the multiple audiences to which it is addressed. Ideology, like all rhetoric, is designed to persuade, but does so by distorting reality in distinctive ways.

Insofar as it assumes rhetorical form, a form open to criticism from a rhetorical perspective, ideology tends to present itself as political philosophy; that is, as arguments in support of a more or less coherent view of the political world. Moreover, ideology is self-referencing; it draws attention to its arguments as such. Its plausibility rests in part on audiences recognizing that argumentation (as opposed to 
authoritative assertion) is what it is about. This means, I will suggest, that argument, though not the sole rhetorical form in which ideology does its work, is indispensable to producing its rhetorical effects. Accordingly, in my analysis of ideology, I will be emphasizing what I term "ideological arguments."

It is important to note here that I am talking of the presentation of arguments to audiences, not the technical properties of the arguments themselves. In other words, ideological arguments need not conform to any particular standards of philosophical coherence or logical consistency; it is sufficient merely that audiences accept them as "coherent" and "logical." This is not to say that there is no correspondence between the formal properties of arguments and audience perceptions of those properties. Rather, it is to acknowledge that one of ideology's crucial functions is to obscure or deny actual contradictions. This can be accomplished covertly through strategies of diversion, or overtly through plausible rationalization. In either, case, however, argumentation is crucial to successful persuasion.

I view "arguments" as claim statements embodying, in Perelman and OlbrechtsTyteca's words, "discursive technique[s] allowing us to induce or to increase the mind's adherence to the theses presented for its assent." ${ }^{3}$ Ideological arguments are statements of this sort employed to support the legitimacy of a particular political system, to justify a particular configuration of power relations in society.

This definition is not as expansive as it may seem. It does not mean that any and every declarative sentence is an argument. Insofar as ideology presents itself as political philosophy, it must at least be plausible as such; it must advance theses, and offer reasons for them. Accordingly, the discursive techniques used in ideological argumentation are not appeals to irrationality and arbitrariness, but rather are at the core of an eminently reasonable inventional process aimed at audiences capable of distinguishing reason-giving from bald assertion and plausible from implausible claims.

Ideological arguments, like all arguments in the public sphere, are founded on the common opinions of audiences. These opinions are conditioned by particular historical circumstances, and may be partially or (in rare cases) wholly false, but, as the substance of arguments, the process by which they are brought to bear on politically significant questions is as rational as that employed in other any context. ${ }^{4}$

My analysis of ideology as rhetoric will be descriptive, primarily. It would be wrong, however, to ignore the evaluative dimension of the rhetorical criticism of ideology. Ideology, inherently, is a distortion of social truth, and not just any kind of distortion. For ideology's function is to help make possible the domination in society of one group over others. ${ }^{5}$ Ideology aims at securing the consent of the governed. It is both alternative and complement to coercion: alternative, in that persuasion is different from and clearly preferable to physical force; complement, in that the right combination of persuasion and physical force works more effectively than either alone to produce political domination. ${ }^{6}$

To note these characteristics of ideology is not necessarily to condemn it. Ideology is essential to the existence of mass societies; we cannot do without it. Politics presupposes the need for legitimation. Even the most coercive political systems require for their survival some degree of popular consent. "Ideology's role," in Paul Ricoeur's words, "is to make possible an autonomous politics by providing the needed authoritative concepts that make it

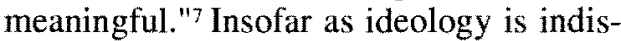
pensible, the moral question becomes not whether it is present but what kind of political system it supports, and by extension, what alternative systems it helps to preclude. 
In this essay, I will confine myself to a discussion of ideology's nature, functions and forms from a rhetorical critic's perspective. To explicate this perspective, I will address three questions: 1) What is ideology?; 2) What does it do?; and 3) How does it do it? My objective is not to press for a "rhetorical theory" of ideology as such, but rather to ask: What can we learn about ideology when we treat it as a kind of rhetoric and apply to it the methods and analytical categories typical of rhetorical criticism? In broad terms, then, I am treating the question: How do the resources of rhetoric help ideology to do its job, to undergird a particular set of power relations in society, to secure the consent of the citizenry to be ruled by a subgroup of itself?

\section{What Is Ideology?}

This question can be answered in many different ways. Joan Robinson once remarked that ideology is like an elephant, difficult to describe, but you know one when you see one. ${ }^{8}$ The variety and complexity of contemporary theories of ideology, however, suggest that her assessment is only half-right. Not only, apparently, does description present great difficulties, but instinctive identification as well.

It is not clear, for example, that it makes sense to talk of "an ideology" or "ideologies." These common locutions suggest distinctive belief systems expressible, in most accounts, as statements about politics. This "traditional" sense of "ideology" suggests that such belief systems operate publicly, as the explicitly acknowledged principles on which politics is based.

But what if ideology resides not just or even mainly in public, political philosophies, but in the structure of everyday (private) language? What if ideology operates covertly rather than openly, at the level of the taken-for-granted rather than in public discussion and debate? What if institutions such as schools serve ideological functions as much through disiplinary rules and regular procedures as through didactic pronouncements?

These possibilities among others reflect contemporary debates about the nature, functions and forms of ideology. My purpose is not to reject them in favor of a more traditional approach. Rather, I am suggesting that insofar as one's goal is to investigate how rhetorical criticism can inform ideological criticism, ideology as political argument is the most fruitful perspective.

The history of ideology as a concept dates from post-Revolutionary France. In 1795, a group of liberal intellectuals led by Destutt de Tracy took as their self-appointed task the creation of a new "science of ideas." These liberals, representing as they did the politics of free thought and expression, and embracing the Enlightenment faith in human rationality, believed that their "ideology" could discover the stand ards by which politically significant claims could be judged. The point was to identify those "ideals" on which the good society ought to be based. The old sources of authority, whether religious or royal, were rejected. A new logic of politics was to replace them. ${ }^{9}$

Significantly, this was not a logic in search of absolutes, but one grounded in rational/empiricist assumptions. De Tracy and his associates believed that the ideals they sought could emerge only from the study of human beings in all their social contexts. The Institut de France they founded became a place for empirical studies in everything from experimental psychology to the history of art. Thus, for the French ideologues, as they came to be called, ideology had a paradoxical character; it was "a system of normative ideas and...an incipient critique of the very notion of absolute norms."10

The ideologues exercised considerable influence on French public opinion for a 
time, particularly among the middle class. But their advocacy of republican values made them a threat to Napoleon Bonaparte's despotic inclinations and during the next twenty years, his posture toward them alternated between ridicule and active repression. Indeed, it was the former strategy that first gave ideology the bad name it still possesses. Though Marx, in the midnineteenth century, was the first to produce a formal critique, it was Napoleon whose oft-expressed contempt for the ideologues transformed ideology from a term of philosophical inquiry into one of opprobrium. He made them out to be sheltered intellectuals, secure in their "ivory tower" but out of touch with political reality. Here again, ideology took on a dual meaning: it was a political philosophy to be sure, but one that, owing to the circumstances of its production, could not philosophize about itself.

In 1845-46, Karl Marx took the critical analysis of ideology a giant step further. His target was not so much the ideologues themselves; they were no longer a political factor. Nor did he stop with a rejection of their liberal bourgeois ideas. Rather, he assailed the very preeminence of ideas in general as determinative factors in human history."

In The German Ideology, Marx argued that a critical analysis of human society had to begin not with the dominant political philosophy or consciousness of the age, but with the system by which people produced the means of their subsistence. ${ }^{12}$ Specifically, it was crucial to realize that liberalism as a way of understanding the political world and of assigning one's role within it sprang from and reflected the capitalist mode of production. The dominant ideas of any historical period were the ideas of the dominating class, and that class's dominance arose in the first instance from its role within the system of production. In capitalism, the bourgeois class dominated; therefore, so did bourgeois ideas. ${ }^{13}$

Admittedly, the ideas of an age possessed a certain appropriateness. Liberal ideas made sense so long as one assumed that capitalism was the way the material world was and/or ought to be. But insofar as these things might not be true, liberal ideology helped to maintain a false consciousness of historical reality. This was so because ideology, though linked integrally to a particular stage of history, presented itself as detached from the material circumstances that gave it birth and conditioned its view of the world. Its advocates presented their ideas as good for all people and all time, not just as good for the ruling class within a finite historical period and socio-economic milieu.

Paradoxically, the "rational/empirical" approach to the discovery of socio-political ideals simply worsened the problem. For to derive those ideals from a study of existing social relations was to guarantee that the resultant ideology was appropriate only to that particular social structure, one tied directly to the capitalist mode of production.

Ideology, then, was not completely false. But because its historical contingency was obscured, it could not provide a satisfactory framework for perceiving the dynamics of the historical process, one in which capitalism was seen as an intermediate rather than final stage.

Since Marx, ideologiekritik has taken many twistings and turnings. To review a century's worth of developments in ideology theory is well beyond this essay's scope. What this brief history of the concept suggests, however, is the essentially dialectical nature of ideology. In its original incarnation, ideology was both a search for absolutes and a challenge to the notion that absolutes could be discovered. In the Napoleonic era, ideology was both the philosophy of the newly empowered middle class, and the product of a detached elite. In Marx's version, ideology was both the historically appropriate consciousness of an era, and an ahistorical distortion of material reality. 
As I will suggest below, this dialectical character of ideology is reflected as well in its functions and forms. Functionally, ideology is indispensible but perverse. Formally, ideology is argumentation, but of a kind that obscures rather than exposes the partiality and distortedness of its truth.

These nineteenth-century conceptions of ideology share a second feature. They all place ideology at the level of ideas, principles, propositions. Ideology, on this view, is not far from what we would call political philosophy. Ideology is not simply an inchoate collection of attitudes, values and beliefs. It is a system of political ideas coherent to the extent that they can be made to seem so (to audiences) via argumentation. ${ }^{14}$

To see ideology as philosophical and argumentative does not, of course, preclude attention to language, or to sociopolitical institutions. ${ }^{15}$ Indeed, such concerns are always part of any fully-rounded rhetorical critique, whether of ideology or anything else. But a point of view that defines ideology essentially as political philosophy directs a critic's attention first and foremost to the most obvious units of that philosophy; namely, propositions and supporting reasons; that is, to arguments and argumentation.

By political philosophy, then, I mean not just the basic tenets of that philosophy, but the entire justificatory edifice on which it rests. Accordingly, it might be more accurate to define ideology as "political apologetics." For it is in the process of arguing for both the truth and relevance of a political philosophy that ideology does its primary persuasive work. Similarly, it is this argumentative process toward which the rhetorical critic of ideology directs his/her attention most productively.

My approach to ideology emphasizes, first, its dialectical nature: ideology as both true and false, functional and dysfunctional, desirable and perverse. Second, that approach incorporates the traditional emphasis (of both the ideologues and
Marx) on idea statements as the chief units of analysis. Such an emphasis necessarily directs a critic's attention to the arguments by which the political philosophy that is ideology is expressed. These two elements of ideology, its dialectical nature and its argumentativeness, can be seen by examining its functions and forms: what ideology does and how it does it. The dialectical character of ideology emerges most clearly from the former; its argumentative character from the latter.

\section{What Does Ideology Do?}

Viewed as political apologetics, what function(s) does ideology perform? One way of approaching this question is to ask what functions in political society need to be performed: "What is to be done?"16

At the most basic level, individuals in society must be willing to cooperate with each other. Such cooperation is necessary in any social group; that is, in any situation where the principle of "might makes right" works against the interests of a majority of group members. Social cooperation, however, is always "unnatural" in the sense that individuals must compromise their particular interests for the sake of the effective operation of the group as a group. Usually, they must settle for less than they want and believe they are entitled to.

The larger the group, the more difficult the reconciliation of conflicting individual interests. In modern liberal societies, the solution to this problem is representative democracy. The claim to legitimacy of democratic political systems rests on the assumption that roughly equal (or, at least, just $)^{17}$ compromises of individual interests are required of all members. This cannot be true, however, for two reasons. First, in mass societies, it is impractical for everyone to share equally in political power, and voting, the only "universal" form of mass political participation, is a notoriously indirect, infrequent and uncertain way of 
affecting its exercise. Therefore, those who rule will always be in a position to benefit disproportionately themselves and those with whom they identify. The only question (albeit, a very significant one) is the extent to which they can do so, and for how long.

Second, and more fundamentally, liberal societies are capitalist societies. Capitalism, by its nature, requires radical disparities in economic power, and these show up both directly and indirectly as disparities in political power. Indeed, the power to compel (through economic necessity) a person to work for wages less than the value of his/her labor (as reflected in the final market value of the product or service) lies outside the realm of politics only if one accepts the dominant ideology's definition of the boundaries of that realm.

In modern societies in general, and in liberal societies in particular, there will always be a gap between the claims of members of the dominant group to rule legitimately and the belief of individuals in society (including those who rule) in that legitimacy. One way of dealing with this gap, of rendering it politically insignificant, is coercion. But even in the most repressive societies, simple coercion is never a completely satisfactory course. It is simply too difficult to physically control all of the people all of the time. In relatively unrepressive societies, an alternative to coercion is all the more essential. Somehow political systems, from the mildly to the intensely repressive, do remain more or less intact for substantial periods of time. Why? If coercion cannot be the whole answer, then what is? In large part, it is ideology that closes the legitimation gap. As Paul Ricoeur puts it, "ideology must bridge the tension that characterizes the legitimation process, a tension between the claim to legitimation made by the authority and the belief in this legitimacy offered by the citizenry." 18

Ideology comprises a set of philosophical principles by which the legitimacy claims of those who rule can be judged. In any mass society, however, the degree to which these principles are understood by and salient to the lives of citizens will vary widely. Philip Converse's famous study of the political belief systems of American voters found that no more than two percent could articulate a coherent set of ideological convictions. ${ }^{19}$ Recent research has confirmed the persistence of this apparent ideological illiteracy. ${ }^{20}$

It would be a mistake, however, to assume that because most people do not seem to possess an articulable ideology that the effects of ideological argumentation are confined to a tiny elite. Ideological understanding may be fragmentary, but nonetheless significant politically. One can believe that the federal government ought to stay out of private affairs, and be able to offer reasons why, without framing this conviction in terms of liberalism or conservatism or reconciling it with the belief that abortion should be illegal.

Ideological justifications of public acts and offices can reassure even if their casuistic subtleties are virtually uncomprehended. To argue at all about political principles suggests that a set of such principles exists as an ideological basis for political society. One need not be involved or be competent to participate in the process of ideological argumentation to take that process as confirmation of the relevance to public life of ideological principles. Ideology, in this case, satifies vicariously, but nevertheless potently.

Ideology's effects, as well as its audiences, are multiple. It seldom acts as a rhetorical pep pill arousing the populace to frenzied heights of political commitment; nor is it a kind of persuasive hallucinogen by which people are maintained in a Never-Never Land of unreality. More often, ideology acts as a tranquilizer, promoting neither intense enthusiasm nor hypnotized passivity, but accomodation and even resignation. ${ }^{21}$

A rhetorical critic of ideology must be alert not only to ideology's range of possible effects and audiences, but to the differ- 
ent circumstances in which it works. In liberal democratic societies, for example, where the coercive power of the state is relatively limited and the power of the citizenry to influence who rules is relatively great, widespread cynicism is most dangerous to the ruling elite. Most people at least need to believe that the standards of legitimacy are accepted as appropriate more or less universally, and that if they are violated too flagrantly, the political system has procedures adequate for restoring its own legal equilibrium. A president of the United States, for example, may break the law; indeed, many people may believe that most presidents have done so. But if a president strays too severely and frequently, he may be impeached and convicted of his "high crimes and misdemeanors." Such, at least, must be the widespread view if the legitimacy gap of representative democracies is to be bridged.

But even in liberal societies, most people need not agree with or even be aware of all of the tenets of a dominant political philosophy. They need only accept, at a general level, that the political system is based on some more or less plausible philosophy, that this philosophy is operative. For example, so long as most people believe that the government of the United States is based on the Constitution, it is not fatal for ideology that many of them, when asked, will be unaware of or will disagree with some of that document's most basic principles. ${ }^{22}$ In other words, the perceived relevance of the dominant political philosophy is as much an ideological issue as its comprehended truth. The significance to their own lives of the dominant political philosophy may be felt as social rather than personal; it is a matter as much of what people believe about the nature of their society as about themselves within it.

Except under conditions of extensive, organized repression, a dominant ideology cannot long survive widespread and deeply-felt public cynicism or disbelief. Should the disjunction between the behavior of rulers and the grounds of their legitimacy become too large, and/or should the beliefs of individuals in society become too much at odds with the dominant philosophy, then no amount of rhetorical legerdemain will be enough to close the legitimation gap. In these circumstances, even in repressive societies, ideology will be unable to contribute very much to holding the system together. And should the repressive apparatus or resolve of the state falter, decades of ideologizing will prove to have been of little use. ${ }^{23}$ That is why an ideology must be historically appropriate; to perform its integrative functions, it must be "true" in an historically-contingent sense.

\section{How Does Ideology Work?}

Arguments advance substantive claims and possess formal characteristics. It is possible to divide the analysis of arguments into these two categories and move on from there. But a rhetorical analysis of argument cannot rest on this form substance dichotomy. Arguments advance claims both in what they say and by what they are. ${ }^{24}$ The former may be explicit, although, in many ways will not be. The latter are always implicit, but rhetorically significant nonetheless, especially in the context of ideological argumentation.

In this section, I want to examine both the explicit and implicit claims of ideological arguments. As to the former, I will use as organizing categories Marx's specification of the two substantive claims ideology advances. As to the latter, I will rely substantially on the analysis of sociologist Alvin Gouldner.

In The German Ideology, Marx argued that political domination occurred on an economic class basis. Clearly, he was thinking primarily of capitalism, and the domination by the employing class. But even if (for Marx, it was "when") the working class became dominant, Marx observed, the same ideological claim would 
have to be made, the claim that the class in power represented not just its own interests but the best interests of society as a whole..$^{25}$ In addition, Marx identified a second generic claim. Dominant classes, he argued, tend to present the existing social system, the system that favors them, as inevitable, natural, timeless, and/or independent of human decision and action. ${ }^{26}$ Beyond specifying them, however, Marx had virtually nothing to say about this inherently rhetorical and argumentative process.

The claim that a ruling group represents the interests of all the people, as opposed to itself only, invites appeals to populist principles. Indeed, it is hard to see how, in liberal democracies, such a claim could be advanced without resort to such appeals. Though, as Ernesto Laclau has noted, populism as a political theme seems at home amid political doctrines from fascism to socialism, from conservatism to liberalism, in a society ostensibly ruled by and for the people, it is an essential theme?

The claim of any ruling group (actual or potential) to represent the common people is inherently ideological. "The people" is always a "cultural fabrication" in Ricoeur's phrase. ${ }^{28}$ Ideology, of necessity, supports political domination. It is in the business of undergirding the rule of one group over society as a whole. To do so, it must present that domination as something different from itself, whether as representative democracy, the rule of God, or the ultimate expression of the Volksgeist. To obscure the reality of political domination, ideology must present the dominant philosophy as representing the interests of all (more or less equally), not just of the ruling group. One way to enhance this presentation is through professions of faith in and subservience to the common people.

How do you get people to think of themselves for political purposes not as workers, or farmers, or Mormons but as Americans? One way is to talk constantly as if that is what they are, and to make membership in such an inclusive group seem desirable. These strategies alone are not enough to create a people, but when wedded to a political philosophy consistent with their message, and in circumstances where economic and social strains are not too great, a politically potent concept of the people can be maintained. Thus when an opposition political party objects to a proposal to reduce the taxes of the wealthy, the sponsoring party can accuse it of "preaching class conflict" without anyone (almost) asking whether the interests of different classes do not inherently conflict. ${ }^{29}$

In representative democracies, the power of the people is both a substantive philosophical claim and a complementary theme. This makes it all the more significant. Ronald Reagan, for example, despite his personal wealth and movie-star background, was well known for his constant and apparently successful efforts to identify with "ordinary people." The significance of this strategy is not simply that it leads a given individual to feel that a leader is like him/her in ways that matter. At a more fundamental level, populist appeals help to make meaningful the very concept of "the people" itself.

Consider the following excerpt from Ronald Reagan's first inaugural address:

\begin{abstract}
Those who say that we're in a time when there are no heroes-they just don't know where to look. You can see heroes everyday going in and out of factory gates. Others, a handful in number, produce enough to feed all of us and then the world beyond.... Now I have used the words "they" and "their" in speaking of these heroes. I could say "you" and "your" because I' $m$ addressing the heroes of whom I speak - you, the citizens of this blessed land. Your dreams, your hopes, your goals are going to be the dreams, the hopes and the goals of this Administration, so help me God. ${ }^{30}$
\end{abstract}

This passage presents an explicit argument followed by a promise. Reagan's thesis is that average Americans are heroes. His proof is an enumeration (quoted only partially here) of the things Americans do, mostly at their jobs. He does not attempt to 
argue explicitly for a definition of heroism that embraces the work of most people; to do so merely would draw attention to the obvious incongruity between what is usually thought of as heroic (the exceptional and uncoerced) and the mundane, obligatory toil of the average factory worker or farmer. But the argument can still succeed rhetorically so long as people are inclined to accept the identification of their work with heroism. ${ }^{31}$

Reagan is banking on this tendency and with good reason. For though few workers would see themselves, in the course of their day-to-day jobs, as Herculean figures, more might feel themselves courageous fellow sufferers, willing to show up each day for work and to do that work well despite its mundaneness and lack of financial rewards. There is, then, a kind of heroism in persistent sacrifice and even in victimage. In this speech, Reagan is signalling that he understands this irony. ${ }^{32}$

Reagan's promise, to make the aspirations of the common people his own, is redeemed in advance by the skill with which he expresses the heroism of working men and women, the extraordinary amid the ordinary. His understanding of the nature of that heroism is a kind of proof that he will make the popular will his master.

Though these populist arguments are not wholly explicit, they are relatively straightforward and require little interpretation. A less obvious implication of his remarks, however, is the claim that the only sufferers in American society worthy of the name "hero" are those who work. All of his examples of heroes are occupational. Insofar as work is understood as heroic sacrifice, its absence might be viewed as disqualification from membership in the legion of American heroes, and, by extension, from the ranks of "true" Americans, period.

This sample of Reagan's rhetoric is one example of the web of explicit and implicit argumentation comprising populist appeals, a theme inherent to Marx's first category of ideological claim: the presentation of the ruling group as representative of the interests of all. Obviously, this sample covers but a small corner of the argumentative space devoted to persuading audiences of the truth of this claim. But it is an instructive case of how ideological arguments identify with commonly held values (of paid work) and attitudes (toward work) to serve their persuasive ends.

Marx's second category of ideological claim is that the existing social system is natural, inevitable and thus, eternal. It represents the way the world is and will always be. To support such a claim, it is essential to defend a theory of human nature, one that accords with the social world as defined ideologically. If human beings are by nature competitive and acquisitive, then a system designed to encourage the expression of these traits is "natural." And if these elements of human nature are so strong that efforts to suppress them are bound eventually to fail, then a competitive, consumption-oriented system is in this sense the inevitable expression of this human nature.

The political economists of the late eighteenth and early nineteenth centuries tended to see human nature as a battleground whereon the forces of rationality on the one hand and passion on the other struggled for control. ${ }^{33}$ Though rational action was to be preferred, passion could never be suppressed successfully. The answer was to channel the passions toward behaviors that would serve rational economic goals. In other words, capitalism. ${ }^{34}$

George Gilder is a modern political economist, and a stalwart of the neoconservative movement in the United States. His ideal economic actor is the entrepreneur, for him a sort of economically optimal version of Captain Blood. That the entrepreneurial instinct is, in the profoundest sense, a part of human nature (or, rather, of male human nature), is suggested in the following argument of why men 
should be encouraged to be autonomous economic actors:

\begin{abstract}
Because of the long evolutionary hunting experience of the race in hunting societies, the provider role accords with the deepest instincts of men. When they are providing for women and protecting them, men feel maculine and sexual; when they cannot perform these roles, as in the welfare culture, they prefer the company of the all-male group at the bar or on the street. ${ }^{35}$
\end{abstract}

The identification of economic behavior and sexual instincts is not accidental or even all that eccentric, particularly in the post-Freudian age. This is true especially when an economic system and the set of power relations it requires are justified not only on utilitarian grounds, but as reflections of human nature. In a secular age in which God's plan is generally an insufficient warrant, only by the latter claim can a particular social system be presented as natural and inevitable.

Arguments from the popular will and arguments from human nature are ideological arguments par excellance. The substantive claims they advance, of a political system's universal representativeness and of a social world's naturalness and inevitability, must be redeemed if a citizenry's willingness to accept a given set of power relations is to be maintained. The consent of the governed may reflect commitment, accomodation and/or resignation, but in liberal democracies, it must be obtained for the ruling group to go on ruling.

The function of persuading people that these claims are true is fulfilled partly by the presentation of plausible reasons. In this sense, ideological argumentation is or ought to be "rational" and can be judged by standards appropriate to such an assumption. But ideological argumentation persuades not only because it offers "good" reasons, but because it presents them in rhetorically powerful ways. It persuades not only by what it says but by what it is.

Ideological arguments occur in "natural language" 36 and in real social contexts.
This means that they persuade via socially meaningful symbols. Rhetorical analysis of their effects must account for the forms and contexts of this symbolizing. Such analysis can occur at several different levels. For example, anthropologist/sociologist Clifford Geertz suggests that no satisfactory account of ideology can neglect its use of tropes and figures:

With no notion of how metaphor, analogy, irony, ambiguity, pun, paradox, hyperbole, rhythm, and all the other elements of what we lamely call "style" operate-even, in a majority of cases, with no recognition that these devices are of any importance in casting personal attitudes into public form, sociologists lack the symbolic resources out of which to construct a more incisive formulation..$^{37}$

Talking about how these rhetorical devices operate is often more a matter of interpretation than description. The methods of the critic of literary texts are liable to be more helpful than the methodological arsenal of the behavioral scientist. ${ }^{38}$

Michael Calvin McGee has suggested another level at which ideological symbolization can take place. He has identified certain common language words and phrases whose invocation can arouse a network of cognitive associations. These "ideographs" are short-hand representations of the ideology to which they refer. Though they may appear as part of ideological arguments, their power at a given moment to invoke attitudes and beliefs independently of such argumentation tends to reinforce that ideology without resort to formal arguments. ${ }^{39}$ Indeed, the very fact that they seem to substitute for such arguments may render ideographs more powerful rhetorically than their referents. This is because an essential element of ideology is its ability to disguise itself. Perhaps, ideographs are the ultimate disguise.

I have argued, however, that ideology's persuasive power can best be appreciated at the level of its arguments. I have justified this view historically by reference to 
ideology theory's origins, and rhetorically, by emphasis on the importance of the substantive political/philosophical claims ideology advances and defends.

A third rationale for emphasizing arguments combines historical and rhetorical elements. Alvin Gouldner has examined what he calls "the dialectic of ideology and technology." 40 Ideology is a product of the modern age of mass industrialized societies. These societies are characterized by a disintegration of old authority structures and social commitments. In their place, the modern age has substituted secularism, rationalism and scientism. Ideology is a form of discourse designed to deal with the anxieties that the loss of the old world created and to accomodate people to the requirements of the new. ${ }^{41}$ What about ideology qualifies it for this role?

The answer is that ideology presents itself in the form of rational, philosophical argument. It presents theses and gives reasons. It supports these reasons not with divine revelation or royal pronouncement but with scientific, empirical evidence. Ideology's argumentation incorporates the rules of conduct of all modern rational discourse. An opportunity for refutation must be afforded to would-be opponents in conditions allowing for each side to fairly present its case. The audience must be allowed to judge these conflicting cases side-by-side in circumstances free of coercion, and so on.

The point of enumerating these formal aspects of ideological argument, and of argument in general, is not to suggest that there is anything wrong with them necessarily, but to observe that such discursive forms favor a certain socio-political configuration; namely, the modern pluralist democratic society. The rules of such societies require that all (responsible) points of view be given an opportunity to be heard. The paradigm case of this form of discourse is the modern university where (ideally) Communists, socialists, liberals, conservatives, etc. can all teach what they wish, bounded only by standards of decorum, that is, a willingness to allow expression of points of view other than their own.

The ideological significance of this liberal form of discourse is that it may obscure as much about the nature of power and its exercise as it reveals. For liberal democracies are not just liberal, they are capitalist. Typically, capitalist systems tend to concentrate large amounts of economic power in a few hands. In a technologically advanced, mass society, this includes power over the means of mass communication. This control may mean that the great bulk of communication people receive accords with the dominant ideology. Though many other points of view may be available, their number and relative obscurity may render them little more than an inchoate babble of distant and alien voices.

Appearances, however, are otherwise. It cannot be denied that opposition voices are allowed; with enough persistence, one can seek them out. This fact can be invoked to demonstrate the basic fairness of the political system, its commitment to truth. Moreover, the system structures its own public argumentation according to the same rules of discourse: open debate, taking turns, etc. Finally, the structure of the discourse itself, its apparent reliance on reasoning and evidence rather than on authoritative assertion, amounts to a recommendation not just of its claims but of the system in which it takes place and thus, which it helps to legitimate.

\section{Conclusion}

I have defined ideology as political apologetics, and have suggested, following Ricoeur, that ideology bridges the tension between the claims to legitimacy of the rulers and the willingness of the ruled to accept such claims. Exploring the nature of this function of ideology further, I have argued that ideology is a kind of social consensus, at once real and unreal, true and 
false. Ideology is real in the sense that most people may believe that a political/ philosophical consensus actually exists; it is unreal in the sense that many individuals may not believe in or even fully comprehend the tenets of the political philosophy an ideology comprises. Ideology is true in the sense that it cannot survive divorced from the historical/cultural context in which it operates, and therefore, must be appropriate to that context; it is false in the sense that it presents itself as a philosophy that serves the universal rather than merely the partial interest and whose dominance is natural and eternal rather than a human, historically-contingent creation.
I have suggested that argumentation is essential to ideology's persuasive task, and that arguments help fulfill that task both substantively and formally, explicitly and implicitly. Ideological arguments advance and defend particular kinds of claims, claims that distort social reality in ways that induce the consent of the citizenry to the arrangements by which they are ruled. Ideological arguments present themselves as a form of discourse which in itself at once legitimates the existing political system and obscures that system's nature. In this sense, as ideology is inherently argumentative, so too are political arguments inherently ideological.

\section{Notes}

1 This definition's emphasis on rhetorical effects derives from Herbert A. Wichelns' pioneering essay "The Literary Criticism of Oratory," in Studies in Rhetoric and Public Speaking in Honor of James Albert Winans, ed. A. M. Drummond (New York: Century, 1925), pp. 181-216.

2 Donald Bryant's definition of rhetoric as "adjusting people to ideas and ideas to people" captures this triangularity. See "Rhetoric: Its Functions and Its Scope," Quarterly Joumal of Speech, 39 (1953), 401-424.

3 Ch. Perelman and L. Olbrechts-Tyteca, The New Rhetoric: A Treatise on Argumentation, trans. John Wilkinson and Purcell Weaver (Notre Dame: University of Notre Dame Press, 1971), p. 4.

4 Perelman and Olbrechts-Tyteca, pp. 7-8.

5 Not all theorists agree that domination inheres in ideology. For example, see Martin Seliger, Ideology and Politics (London: Allen and Unwin, 1976). For a clear statement of the point of view that ideology inherently implies domination, see John B. Thompson, Studies In the Theory of Ideology (Berkeley: U of California Press, 1984), pp. 73-147.

6 One recalls comedian Professor Irwin Corey's remark that you can get more with a gun and a kind word than with a kind word.
7 Paul Ricoeur, Lectures On Ideology and Utopia (New York: Columbia University Press, 1986), p. 12.

8 Quoted in R.B. Carson, Economic Issues Today (New York: St. Martin's Press, 1987), p. 10.

9 George Lichtheim, "The Concept of Ideology," in The Concept of ldeology and Other Essays (New York: Random House, 1967), pp. 4-11.

10 Lichtheim, p. 7.

11 "The German Ideology," in The Marx-Engels Reader, ed. Robert C. Tucker (New York: Norton, 1978), pp. 154 and 165.

12 "The German Ideology," p. 157.

13 "The German Ideology," pp. 172-173.

14 This too is an important distinction given the similarity between many definitions of ideology and of "culture." For example, political sociologist Ronald Inglehart defines the latter as "a system of attitudes, values and knowledge that is widely shared within a society and transmitted from generation to generation." See Culture Shift (Princeton: Princeton University Press, 1990), p. 18.

15 For a semantic emphasis, see Michael Calvin McGee, "The Ideograph: A Link Between Rhetoric and Ideology," Quarterly Journal of 
Speech 66 (1980), 1-16. For an emphasis on institutions, especially of the state, see Louis Althusser. "Ideology and Ideological State Apparatuses," in Lenin and Philoscphy and Other Essays (New York: Monthly Review Press, 1971), pp. 127-186.

16 Borrowing the title from Lenin's famous tract is not gratuitous, for Lenin particularly is famous for demanding that Communism not wait for the ineluctable laws of history to bring it about, but instead, help history along by a program of political education aimed at workers, a program distinctly philosophical in content. See What Is To Be Done?, (Peking: Foreign Languages Press, 1975).

17 John Rawls's famous formula for a just distribution of social benefits requires that each new benefit distribution should aid the least advantaged members of society at least as much as any other group. This apparently unequal scheme, however, derives from an assumption of equality in society's "original position"; that is, at the imaginary point at which democracy's social contract is signed. See A Theory of Justice (Cambridge: Belknap Press of Harvard University Press, 1971).

18 Ricoeur, Lectures On Ideology and Utopia, p. 12.

19 Philip Converse, "The Nature of Belief Systems in Mass Publics," in Ideology and Discontent, ed. David Apter (New York: Free Press, 1964). Converse avoids the term ideology, but his use of the alternative "belief system" is consistent with my use of "ideology" in this essay.

20 See Eric R.A.N. Smith, The Unchanging American Voter (Berkeley: University of California Press, 1990).

21 For a discussion of the various responses that ideology can produce, see Goren Therborn, The Ileology of Power and the Power of Ideology (London: Verso, 1982), pp.93-100.

22 Robert Lane's famous study of ideology in an American town is an example of the oft-recorded phenomenon that citizens of the U.S. often disagree with the principles upon which their system of government is ostensibly based. See Political ldeology (New York: Free Press of Glencoe, 1962).

23 One of the most remarkable things about the rapid disintegration of ruling regimes in Eastern Europe surely has been the the apparent absence, despite generations of what the West often has viewed as effective indoctrination, of a substantial residual effect of Communist ideology.

24 Speech act theory is of obvious relevance here. See J. L. Austin, How To Do Things With Words (Cambridge: Harvard University Press, 1975).

25 "The German Ideology," p. 174.

26 "The German Ideology," p.173. See also Anthony Giddens, Central Problems In Social Theory (Berkeley: University of California Press, 1979), p. 195.

27 Politics and Ideology In Marxist Theory (London: New Left Books, 1977), pp. 173-175.

28 Lectures On Ideology and Utopia, p. 13.

29 In the latest battle over reducing the U.S. Government tax on capital gains, the Democratic Party's opposition succeeded only because it was expressed in terms of equity and faimess. Indeed, any explicit reference to classes might have raised questions as to the class membership of most Democratic politicians.

30 "Inaugural Address of Ronald Reagan, January 20, 1981," in Contemporary American Speeches, eds. Wil A. Linkugel, et al,, (Dubuque: Kendall Hunt, 1982), p. 376.

3 In Aristotle's terms, the argument works via an enthymeme. The identification of heroism with work need not be explicated because it is based on commonly held values and attitudes. Indeed, this argument can work only enthymematically, because once the assumptions underlying it are exposed and dissected, they cease to be plausible. See The Rhetoric and Poetics of Aristotle, trans. W. Rhys Roberts (New York: Modern Library, 1954), pp. 21-22 [1355a; 3-10].

32 Bruce Springsteen signalled the same thing with his hit song "Born in the U.S.A." In this case, the irony is deepened with the identification of patriotism with feelings of economic exploitation. It was not by accident, that the Reagan Administration at various points tried to appropriate Springsteen's lyrics as their own song.

33 Of course, this was hardly a new insight. See, for example. Plato's Phaedrus and the allegory of the charioteer. The innovation of the liberal political economists, however, was to apply the notion of rationality vs. passion to individual economic behavior. 
34 See Albert $O$. Hirschman, The Passions and the Interests (Princeton: Princeton University Press, 1977).

35 Wealth and Poverty (New York: Basic Books, 1981), p. 136.

36 I borrow the term from Blair and Johnson's characterization of informal logic: "the area of logic which seeks to develop standards, criteria and procedures for the interpretation, evaluation and construction of arguments and argumentation used in natural language." See J. Anthony Blair and Ralph H. Johnson, "The Current State of Informal Logic," Informal Logic, 9 (1987), p. 148.

37 "ldeology As a Cultural System," The Interpretations of Cultures (New York: Basic Books, 1973), p. 209.

38 This is not to say that the latter are not useful at all. For example, advertisements, political and commercial, are now often "pre-tested" on focus groups by using galvanic skin response and other tests to determine the intensity and valence of audience reactions. Responses are recorded even down to the level of individual words.

39 McGee, "The Ideograph," pp. 5-7. Elsewhere, McGee and Martha Anne Martin have attempted to specify some of the technical characteristics of ideological arguments. See "Public Knowledge and Ideological Argumentation," Communication Monographs, 50 (1983), 47-65.

40 The Dialectic of Ideology and Technology (New York: Oxford University Press, 1976).

41 With apologies to Gouldner, I am summarizing and thus dissolving many of the intricacies of his analysis. I am relying particularly on his discussion of "Ideological Discourse as Rationality and False Consciousness," The Dialectic of Ideology and Technology, pp. 23-66.

MICHAEL WEILER

DIVISION OF COMMUNICATION STUDIES

EMERSON COLLEGE

100 BEACON STREET

BOSTON, MA 02116

\section{EDITORIAL INFORMATION}

EDITORIAL POLICY: INFORMAL LOGIC publishes articles which advance the dialectic in reasoning and argumentation in theory and practice, including but not restricted to: theory of argument, fallacy analysis and fallacy theory, criteria of good argument, rationality and argument, psychology of argumentation, argument fields, theory of critical thinking, the teaching of argumentation, informal logic and critical thinking, and related topics in cognate fields. Articles, reviews, and critical studies are blind refereed.

There are wo related primary criteria for acceptance of articles with a theoretical focus or interest. First, the article should advance the dialectic or at the very least constitute an interesting comment on it. That is, it should cogently present an argument, objecfion, interpretation, or position that is an advance in relation to the historical background of issues and controversies; or else it should cast the issue addressed in a worthwhile new light.

Second, the article should touch base with the literature on its topic. It should use or mention pertinent literature and should discharge the burden of proof established by relevant items in that literature.

The primary criteria for acceptance of articles devoted to the teaching of informal logic, critical thinking, or argumentation include originality, utility, timeliness, and evidence of the effectiveness of proposed methods, materials, etc.

The standard criteria for scholarly publicationtopic fit with the subjects covered by the journal, adequacy of coverage to the issue addressed, the clarity, organization, and literateness of the prose, and the conceptual clanty and cogency of its argumentationapply to all articles, notes, and reviews. Some of these criteria may be overridden if a paper has outstanding compensating features which warant its publication.

MANUSCRIPT PREPARATION: Three copies required from Canada and USA (preferred from elsewhere), typewritten or near-letter-quality printed, double-spaced, one side only, minimum $2.5 \mathrm{~cm}\left(1^{*}\right)$ margins all around, on $21 \times 29.5 \mathrm{~mm}\left(8.5^{\prime \prime} \times 11^{\prime \prime}\right)$ bond paper. Copies should not be stapled but instead bound with paper clips. Notes and references, also doublespaced, should be on separate pages at the end of the manuscript. Symbols should be typewriter-compatible. Diagrams, illustrations, or tables should preferably be professional-quality camera-ready copy on separate sheets, with their location in the manuscript clearly indicated. Authors should not identify themselves on the manuscript, but only in an attached letter giving title and affilation (if any) and complete mailing address. As well, overtly self-referential citations should normally be avoided. Manuscripts will not be returned unless sufficient Canadian or international postage is prepaid. (Authors should retain a copy.) Authors of accepted manuscripts will (1) be asked to send a copy of the final version in WordPerfect (preferably) or ASCII on a DOS floppy disk, as well as two hard copies; (2) be requited to submit an abstract (maximum 100 words); (3) receive 10 offprints free and rights to reproduce additional copies.

All correspondence should be directed to: INFORMAL LOGIC

Department of Philosophy University of Windsor

Windsor, Ontario, Canada N9B 3P4

Phone: (519) 253-4232, ext. 2332

Fax: (519) 973-7050

Electronic mail: infolog@ucc.uwindsor.ca 